\title{
Gregorio de Nacianzo y Paladio de Helenópolis contra los malos obispos: ¿diatriba cínica o rethorical display? ${ }^{1}$
}

\author{
Silvia ACERBI \\ Universidad de Cantabria \\ acerbis@unican.es
}

\begin{abstract}
Estoy apegado sólo a la palabra y no me lamento de los sufrimientos que he vivido por tierra y mar para conquistarla. Quisiera, en cualquier caso, que tanto yo como quien sea amigo mío, poseyéramos la fuerza de la elocuencia (ton logon kratos). Es lo primero que yo he abrazado y sigo abrazando por encima de todo, se entiende, sólo después de las cosas divinas y las esperanzas depositadas en lo que está más allá de nuestra vista.
\end{abstract}

Gregorio de Nacianzo, Orat. IV 100,3

En un reciente artículo sobre las elecciones episcopales en la Antigüedad Tardía significativamente titulado «The Rhetoric of Rules and the Rule of Consensus», Peter Van Nuffelen ha tratado el importante papel desempeñado por la retórica en la interpretación de textos de contenido aparentemente tan poco retórico como son los cánones eclesiásticos de la Antigüedad Tardía, en vista a su aplicación en las elecciones episcopales: the rhetoric of law" -escribe-presupposes its authority, but does not always respect the strict letter of the law. Pero el autor también aclara que the rhetoric of law does not mean that law was only seen as rhetoric. On the contrary, it implies a recognition of its possible power ${ }^{2}$. Estas agudas observaciones vienen a ratificar, de algún modo, las afirmaciones de Ramón Teja en otro estudio reciente sobre el poder de la retórica en los escritores cristianos antiguos y, como consecuencia, «los análisis exegéticos a que se ven obligados los historiadores de hoy si desean alcanzar un mínimo de objetividad histórica al margen de polémicas y apologías»³. Quizás no esté de

\footnotetext{
${ }^{1}$ Este trabajo está enmarcado en el ámbito del Proyecto de Investigación: HAR 2010-15957.

${ }^{2}$ P. Van Nuffelen, «The Retoric of Rules and the Rule of Consensus», J. Leemans et alii (eds.), Episcopal Elections in Late Antiquity, Berlin-Boston, 2011, pp. 256-257.

${ }^{3}$ R. Teja, «Constantino frente a Constancio II: la deformación de la memoria histórica entre 'arrianos' y 'nicenos', Constantinus: ¿el primer emperador cristiano? Religión y política en el siglo IV, Actas del Congreso Internacional celebrado en Barcelona el 20-24 marzo 2012, en prensa.
} 
más recordar que la contraposición existente entre la historia y algunos sub-géneros de la retórica como la diatriba o el panegírico fue expresada ya por Luciano de Samosata en su conocido Diálogo Cómo debe escribirse la historia cuando señalaba que «la única preocupación del encomiasta es elogiar y agradar por cualquier procedimiento, y le importa poco conseguir su objetivo mintiendo; la historia, en cambio, no puede admitir una mentira» ${ }^{4}$.

Me ha parecido importante el recurso a estos juicios antiguos y modernos sobre el papel de la retórica en la literatura cristiana para valorar y comprender un hecho que ha llamado con frecuencia mi atención al sumergirme en la lectura de las fuentes de los siglos IV y V. Son muy abundantes y variados los textos de autores que critican con una dureza, en apariencia muy poco cristiana, la indignidad y el bajo nivel moral de muchos de los obispos, en su mayoría colegas, de la época. Ciertamente no existen en la literatura clásica invectivas a los sacerdotes paganos similares a aquellas con que los escritores cristianos han satirizado a sus propios obispos. Al contrario, paganos como Amiano Marcelino ensalzaron la conducta y forma de vida de la mayoría de los obispos de provincias, en contraposición con el de Roma ${ }^{5}$, y Juliano el Apóstata exhortaba a los sacerdotes de los cultos tradicionales a imitar la conducta de los obispos cristianos ${ }^{6}$. Al margen de otros motivos que no procede recordar aquí, una causa habría que buscarla precisamente en la enorme importancia desempeñada por la retórica en la literatura cristiana desde el momento en que ésta vio la luz en los tratados polémicos y apologéticos contra paganos y herejes; un carácter que nunca abandonó en la Antigüedad y que pronto se puso al servicio de las polémicas entre obispos, polémicas en las que la sátira era utilizada como principal recurso literario. Al comentar los versos de la Autobiografía en que Gregorio de Nazianzo describe su despedida del emperador y de la corte de Constantinopla sin humillarse, como habrían hecho otros obispos en su lugar ${ }^{7}$, Claudia Rapp califica el tono y la forma del pasaje como una muestra eficaz de exhibición retórica: a skillful and deliberate combination of venerable phisical appearance, episcopal status and rhetorical display ${ }^{8}$. Yo añadiría que se trata de un magnífico ejemplo de la invectiva satírica de carácter menipeo precisamente en la pluma del obispo cristiano que pasaría a la historia con el calificativo de el Teólogo. Los numerosos loci en que Gregorio de Nacianzo se desahoga en sus críticas a los colegas en el episcopado

\footnotetext{
${ }^{4}$ Luc. Samos., Diálogo, 59, 7

${ }^{5}$ Am. Marcell., Historiae, XXVII; 3,15.

${ }^{6}$ Iul., Ep. 84, «A Arsacio, sacerdote supremo de Galacia».

${ }^{7}$ Carmen II, 1,11, vv.1871-1901. La amplia obra poética de Gregorio de Nacianzo solo está disponible en su totalidad en la antigua edición de Caillau (Paris 1840-1842) reproducida en la Patrologia Graeca 37. Pero existen ediciones críticas modernas de algunos de los poemas que más he utilizado y que deben ser tenidas en cuenta. Para la Autobiografía = Carmen II, 1,11, Saint Grégoire de Nazianze, Ouvres Poétiques, texte établi par A. Tuillier et G. Bady; traduit et annoté par J. Bernardi, Collect. G. Budé, Paris 2004. Para el poema Sobre los obispos = Carmen II,1,12, Gregor von Nazianz, Über die Bischöfe (Carmen 2,1,12), Einleitung, Text, Übersetzung, Kommentar von B. Maier, Paderborn, 1989. Me he servido también de la magnífica traducción italiana Gregorio Nazianzeno, Poesie/2, traduzione e note di C. Crimi (Carmi II, 1,10 e 12-50) e di I. Costa (Carmi II,1,51-99 e II,2), Città Nuova, Roma, 1999.

${ }^{8}$ C. Rapp, Holy Bishops in Late Antiquity. The Nature of Christian Leadership in an Age of Transition, Berkeley-Los Angeles, 2005, p. 272.
} 
constituyen algunas de las mejores muestras que nos ha legado la Antigüedad Tardía de literatura satírica, comparables por su calidad artística a la ironía burlesca de la que hizo gala el antes mencionado Luciano de Samosata en sus Diálogos. Los versos yámbicos de que se sirve el obispo capadocio en la mayoría de sus poemas representan y constituyen una especie de proceso judicial contra los malos obispos con una carga retórica de altísimo valor literario.

\section{LA IMAGEN DEL MAL OBISPO EN LOS POEMAS PERSONALES DE GREGORIO DE NACIANZO}

Quizás esté por escribir una obra que bien podría titularse La imagen del obispo tardoantiguo visto por los propios obispos. En un pasaje muy conocido, el Nacianzeno califica a sus colegas de lupi, y es inevitable que se asome a la mente del lector la idea de un episcopus episcopo lupus. Fue, quizá, el obispo capadocio quien, impulsado por unas peripecias vitales bien conocidas, descargó con más dureza su frustración existencial mediante severísimas críticas al episcopado de su tiempo. Hombre de una profunda humanidad y una enorme sensibilidad, Gregorio sufrió como pocos la incomprensión de sus colegas o, al menos, experimentó en sus carnes esa sensación de radical incomprensión. De origen aristocrático y de exquisita formación intelectual, vivió obsesionado por el bajo nivel moral y la escasa preparación de gran parte de los máximos exponentes de la jerarquía eclesiástica. Contribuyeron a configurar esta visión pesimista sus difíciles experiencias vitales y un temperamento que podríamos definir hipocondríaco. Circunstancias que acusó de una manera exacerbada cuando, en el 381, se vio obligado a abandonar la cátedra episcopal de Constantinopla a consecuencia de las críticas de sus colegas, reunidos en el que pasó a la historia como Segundo Concilio Ecuménico ${ }^{9}$. Una vez retirado a su Capadocia natal, expresó su amargura y decepción en sus escritos posteriores, especialmente en su Oratio 42, reelaboración del discurso de despedida en Constantinopla, y en una larga serie de poemas autobiográficos y apologéticos que ocuparon sus últimos años hasta la muerte en el $390^{10}$.

Pero Gregorio de Nacianzo no fue una excepción entre los obispos que se desahogaron en sus críticas contra los colegas en el sacerdocio. Las fuentes, especialmente

${ }^{9}$ La vida de Gregorio es una de las mejor conocidas de la Antigüedad porque quedó plasmada en una famosa Autobiografía de 1949 versos, en otros numerosos poemas de carácter personal y en su rica y variada correspondencia. Entre las biografías modernas, me limitaré a señalar la ya clásica de P. Gallay, La vie de Saint Grégoire de Nazianze, Lyon-Paris, 1943 y las más recientes de J. Bernardi, Saint Grégoire de Nazianze. Le théologien et son temps (330-390), Paris 1995 y J.A. McGuckin, St Gregory of Nazianzus. An Intellectual Biography, Crestwood, NY, 2001; para sus vivencias en Constantinopla, imprescindibles para entender el presente ensayo, es fundamental N. Gómez Villegas, Gregorio de Nacianzo en Constantinopla, Madrid, 2000.

${ }^{10}$ Cfr. N. McLynn, «The voice of conscience: Gregory of Nazianz in retirement», Vescovi e pastori in epoca Teodosiana. XXV Incontro di studiosi dell'Antichità cristiana, Roma, 1997, vol. II, pp. 299-308; sobre la concepción de su autobiografía en cuanto autoapología, vid. J. A. McGuckin, «Autobiography as Apologia in St Gregory Nazianzen», Studia Patristica 37, 4 (2001), pp. 160-177 
a partir de Constantino, son muy numerosas y de muy variada naturaleza, pero en este ensayo dedicado a la eficacia de la retórica entre los autores cristianos, me limitaré a un sondeo entre los escritores de finales del siglo IV e inicios del V, en los que las influencias de las tradiciones literarias greco-latinas como la comedia, la sátira y la invectiva literaria, entre otras, contribuyeron a dar nueva forma al discurso retórico en la pluma de los autores cristianos más profundamente helenizados. Mi análisis se reducirá a aquellos que se expresaron en griego, a pesar de ser consciente de la importancia de otras lenguas como el siríaco para Oriente o el latín para Occidente. Baste recordar, por ejemplo, las acerbas críticas contra el clero de su época de un escritor latino, laico en este caso, como Sulpicio Severo que se inspiró en un clásico como Salustio. Solamente citaré un pasaje en que estigmatiza la conducta de los obispos galos de finales del siglo IV:

Observamos que todo se altera y alborota, especialmente por las discordias entre los obispos, y que la situación se ha degradado debido a ellos por el odio o el favoritismo, por el miedo, la falta de firmeza, la envidia, el partidismo, la molicie, la avaricia, la arrogancia, la desidia y la insolencia (odio et gratia, metu, inconstantia, invidia, factione, libidine, avaritia, arrogantia, somno, desidia depravata). Finalmente, la mayoría, llevada de sus extravagantes proyectos y obstinadas pasiones (insaniis consiliis et pertinacibus studiis) seguían luchando contra unos cuantos hombres sensatos: en medio de todo ello, el pueblo de Dios y todos los hombres de bien eran objeto de escarnio y de burla ${ }^{11}$.

Volviendo a Gregorio, hay que tener presente hasta qué punto su experiencia en el Concilio del 381 quedó grabada a fuego en su mente. Lo dejó entender cuando, un año después, se excusó por carta de no asistir a un nuevo concilio convocado por el emperador Teodosio en la misma Constantinopla: «No he visto ningún concilio que tenga un final feliz, o que ponga fin a los males, en vez de aumentarlos. No hay más que enfrentamientos continuos y luchas por el poder» (Greg. Naz., Ep. 130). Sin duda esta imagen tan peyorativa de los concilios era compartida por otros hombres de la Iglesia de la época. Así, el historiador eclesiástico Sócrates escribía a mediados del siglo $\mathrm{V}$ que todos los concilios posteriores a Nicea habían sido, no solo innecesarios, sino también perniciosos ${ }^{12}$. Por las mismas fechas, León Magno se expresaba en estos términos: "Cada vez que por el bien de la Iglesia se reúne una asamblea de obispos resulta difícil que la ambición de personas sin escrúpulos no lleve a cabo complots para conseguir algo que supera toda mesura ${ }^{13}$. Pero, como decía antes, fue especialmente en sus poemas personales donde Gregorio dejó vía libre a la expresión de su amargura y su rencor. Si he utilizado anteriormente el calificativo de sátira menipea aplicado a las expresiones del Nacianzeno es porque muchas de éstas pueden resultar ofensivas para los oídos modernos no familiarizados con la parrhesía de los escrito-

\footnotetext{
11 Sulp. Sev., Cronica II, 51, 5.

12 Socr., HE 2,1,6; cfr. et. 2,10,2; 2,40,21.

13 León Magno, Ep. 56.
} 
res cristianos de esta época. Este es el caso del pasaje en que compara a los clérigos de Constantinopla con los asnos y que evoca la sátira «Menipo o la necromancia» en la que Luciano de Samosata condena a los ricos y a los banqueros a reencarnarse en estos animales ${ }^{14}$ : vituperando la altanería que manifiestan algunos por ser clérigos de la capital del Imperio se pregunta Gregorio: «iAlguna vez ha reclamado un asno de ciudad un puesto superior al de un asno de aldea? No, pues será siempre asno, aunque viva en la ciudad» (Carmen II, 1,12, vv. 784-786).

Los reproches del Teólogo a sus colegas en el episcopado tienen como punto de partida las deficiencias en su reclutamiento, la falta de selección y su nula preparación intelectual. En un artículo que lleva el expresivo título, tomado de una frase del propio Gregorio, «Acteurs de pantomimes, trafícants du Christ, flatteurs de femmes...», $\mathrm{K}$. Demoen ha recogido especialmente las críticas relativas al bajo nivel cultural de los obispos $^{15}$. Lo expresa eficazmente el Nacianzeno con esta metáfora tomada del reino de las aves:

Se dice que, muy sabiamente, el águila expone el rostro de sus crías a los rayos del sol y así distingue a los bastardos de los que son suyos. Rechaza aquellos y se convierte en padre de los segundos. Nosotros, por el contrario, entronizamos a la cabeza del pueblo a todos, con la única condición de que ambicionen el cargo. No controlamos nada del presente ni del pasado: ni su conducta, ni su doctrina, ni sus amistades (Carmen II, 1, 12, vv. 371-379).

Según Gregorio no se ven excluidos de la cátedra episcopal, evidentemente con una exageración retórica, ni los amantes de los caballos, ni los actores del teatro, ni los abogados corruptos, ni los jueces malvados, ni los músicos afeminados, ni los recaudadores de impuestos, ni los soldados chantajistas, todos los cuales de un día para otro se pueden convertir en obispos. Así comienza su sátira sobre los repentinos cambios de profesión: «Ayer estabas entre bailarines afeminados y hacías de pregonero de bodas contorsionándote entre cánticos procaces [...], ahora te has transformado en consejero de vírgenes y de esposas. ¡Qué sospechosa es tu virtud a juzgar por las anteriores costumbres! ¡Ayer Simón Mago, hoy Simón Pedro!» (Carmen II, 1,12, vv. 425-430).

Esta falta de criterios de selección era un mal muy generalizado en toda la Iglesia de la época, que había crecido y se había expandido con una sorprendente rapidez al amparo de la protección imperial. Se pueden recordar aquí -pero volveremos sobre ello- las acusaciones que algunos años después hará a Teófilo de Alejandría otro obispo, Paladio de Helenópolis.

Era costumbre suya no ordenar a personas de valor y sensatas, si no era por error, pues no quería tener bajo su dependencia más que imbéciles (anoétoi), dado

\footnotetext{
${ }^{14}$ Luc. Samos., Diálogo 38

${ }^{15}$ K. Demoen, «Acteurs de pantomimes, trafícants du Christ, flatteurs de femmes... Les évêques dans les poemes autobiographiques de Grégoire de Nazianze», Vescovi e pastori, op.cit. vol. I, pp. 287-298. Vid. también el breve artículo de A. Louth, «St Gregory Nazianzen on Bishops and the Episcopacy», ibidem, pp. 281-285.
} 
que prefería mandar sobre éstos antes que escuchar a personas inteligentes (phronímoi); y, a pesar de todo, queriéndolo o no, a veces ha sido vencido por la Providencia del Señor (Pal. Hell., Diálogo V, 95-99).

No sin dejar traslucir su orgullo aristocrático, el Nacianzeno ridiculiza con una crudeza rayana en lo caricaturesco los bajos orígenes sociales de muchos de sus colegas en el episcopado:

Que ningún campesino, que ningún carpintero, que ningún zapatero, que ningún cazador, que ningún herrero quede excluido [...]; y el carpintero arroje lejos el poderoso hacha, el campesino el arado, el zapatero los cueros, el cazador la lanza, el herrero las tenazas. Venid aquí todos, rodead por todas partes la mesa divina, apiñados en torno a ella [...] (Carmen II, 1,13, vv. 100-107).

Este orgullo aristocrático era compartido por otros obispos capadocios como Basilio de Cesarea, tal como queda reflejado, por ejemplo, en una epístola en que denigra los bajos orígenes sociales de sus rivales arrianos de Capadocia:

Cuanto más decaen o se debilitan las iglesias, más florece entre los hombres el afán de poder. Y es a pobres hombres, a esclavos hijos de esclavos, a quienes ha ido a parar ahora el nombre de obispo [...] Son individuos como éstos los que acaban de expulsar de Nisa a mi hermano para poner en su lugar a un hombre, o más bien, a un esclavo que no vale más que unos óbolos [...] A la aldea de Doara han enviado a un hombre de perdición, un siervo de los huérfanos que ha huido de sus dueños. Querían así congraciarse con una mujerzuela atea [...] Éste es el ultraje infligido al nombre de obispo (ep. 239).

Se ha intentado explicar de muchas maneras esta actitud de Gregorio hacia los colegas en el episcopado. Algunos autores califican incluso al capadocio de carácter paranoico ${ }^{16}$. Frente a juicios como éstos, coincido plenamente con J.A. McGuckin en que su poesía debe de ser analizada in terms of its own matrices and intelectual context, that its the retorical and literary spectations of Second Sophistic Rhetoric ${ }^{17}$. Como antes recordaba, hay que interpretar sus críticas en el marco de lo que significaba la parrhesia para los escritores y filósofos antiguos, en su caso una parrhesia muy próxima a la de los cínicos. No es casual que en uno de sus poemas recuerde

\footnotetext{
${ }^{16}$ Así K. Demoen, op. cit, pp. 288-289: le caractére paranö̈aque du Theologien explique le ton à la fois plaignant et apologétique de plusiers lettres, discours et poèmes datant des époques constantinopolitaine et postérieure; sobre las características patológicas de la personalidad del Nacianzeno han especulado muchos autores: «neurótico degenerado» (E. Rapisarda, «Il pessimismo di Gregorio Nazianzeno», Miscellanea di Studi di Letteratura Cristiana Antica 3, (1951), pp. 136-161); víctima de «depresión clínica» al que su obra poética sirvió de medicina para sus males físicos y mentales (P.L.Gilbert, Person and Nature in the Theological Poems of Sain Gregory of Nazianzus, Washington DC, 1994); el listado se podría alargar mucho más...

17 J. A. Mcguckin, «Gregory: the Rethorician as Poet», J. Bortnes-T. Hägg (eds.), Gregory of Nazianzus. Images and Reflections, Copenhagen, 2006, p. 194.
} 
que Juan Bautista había sido víctima de su parrhesia frente a Herodes Agripa (Carmen II, 1, 14, v. 65).

Esta mentalidad elitista, producto de una exquisita formación retórica y de la nobleza de cuna, común por lo demás a todos los denominados Padres Capadocios y a otros muchos Padres de la Iglesia, se trasluce una y otra vez en sus ataques a los obispos participantes en el Concilio del 381, a los que consideraba responsables de su dimisión. Acudiendo una vez más al recurso literario de la diatriba cínico-estoica ${ }^{18}$, Gregorio escribe que procedían de la administración de los impuestos, de las oficinas de los cambistas -algunos incluso del arado pues se les ve todavía tostados por el sol, o de los bancos de remo pues mantienen el olor a salitre, o de la fragua, pues ni siquiera se han lavado el hollín de su piel- para concluir con esta afirmación poco piadosa: «Creen que tienen el poder sobre los asuntos celestiales, pero apenas saben hablar y no aciertan a contar los dedos de sus pies o de sus manos» (Carmen II, 1 12, 154-175).

Aunque las deficiencias en el proceso de selección son bien conocidas, el bajo nivel moral de muchos obispos se explica también porque el máximo cargo eclesiástico se había convertido en un instrumento de promoción social y económica altamente apetecido y fuente de orgullo, ambiciones y corruptelas como denunciaban muchos monjes al rechazar la ordenación episcopa ${ }^{19}$. Por los mismos años en Roma Jerónimo satirizaba, en un texto de exquisita calidad literaria y también de indudable carga retórica, el hecho de que el sacerdocio cambiaba profundamente el tenor de vida al convertirse no sólo en un medio de promoción social, sino también de captación de las simpatías de las mujeres de la aristocracia romana, lo que recuerda el calificativo «halagadores de mujeres» empleado por el Nacianzeno:

Vergüenza me da contar lo demás, no sea que alguien piense que estoy haciendo sátira en vez de brindarles mi consejo. Otros hay -hablo sólo de los de mi propio estado- que ambicionan el presbiterado o diaconado para poder ver más libremente a las mujeres. Toda su preocupación es el vestido, andar bien perfumados, y que el pie no se mueva dentro del zapato como si fuera un fuelle. Los cabellos, ensortijados, llevan las señales del rizador, los dedos lanzan destellos por los anillos, y para que la humedad de la calle no les moje la planta del pie, apenas si pisan el suelo con la punta de los zapatos. Cuando vieres a gentes semejantes, tenlos más bien por pretendientes que por clérigos ${ }^{20}$.

${ }^{18}$ Es la expresión que utiliza C. Crimi, op. cit. 1999, p.75, n. 6 refiriéndose al Carmen II, 1, 12, pero puede aplicarse a casi todos los que aquí recogemos.

19 Vid. ahora R. Teja, «La figura del monje-obispo en el Oriente cristiano: ¿incompatibilidad o complementariedad?», J.A. García de Cortázar-R. Teja (Coord.) Monjes y obispos en la España del Románico, Aguilar de Campoo, 2013, pp. 10-41.

${ }^{20}$ Hier, Ep. 22, 28 «A Eustoquio» (J. B. Valero, San Jerónimo. Epistolario, ed. y trad. esp., Madrid, 1993, BAC 530). Recordamos que Jerónimo se refiere a la misma época en que Amiano Marcelino criticaba al obispo de Roma, Dámaso, por llevar un tren de vida fastuoso, similar al de un aristócrata romano: Am. Marc., Historiae XXVII, 3, 14-15; por su forma de vida, el papa Dámaso fue recordado por Basilio de Cesarea desde la lejana Capadocia en estos términos: «Tratándose de una persona orgullosa y altanera, que está sentada en un trono de no sé qué altura que no le permite escuchar a los que le dicen la verdad desde el ras del suelo [...]», Ep. 215. 
El propio Gregorio tenía como una espina muy clavada en la mente el haber sido substituido, tras su obligada renuncia al trono de Constantinopla, por un senador, Nectario, que había cambiado su carrera política por la eclesiástica sin ni siquiera estar bautizado. Aunque nunca menciona a obispos concretos en sus diatribas ${ }^{21}-$ la única excepción fue el cínico Máximo ${ }^{22}$ - no puede olvidar su caso cuando recuerda «a otro elevado de improviso a una cátedra extraña en la cual él había sido sentado por Dios» (Carmen II, 1, 10, vv.14-15). Seguramente estaba también presente la figura de Nectario en su acerada pluma cuando profería lamentos como éste:

Nuestra organización está sumida en una situación desastrosa [...] Lo afirmo entre lágrimas. Nos sentamos en el trono de manera indigna, nosotros, los líderes del pueblo, los maestros del bien. Hemos sido designados para nutrir las almas con alimento divino, pero nosotros mismos estamos hambrientos; actuamos como médicos, pero en realidad somos cadáveres que sufren innumerables males (Carmen II, 1,11, vv.20-33).

O bien en este otro pasaje en que vuelve a desahogar su frustración, humana y religiosa, en unos versos en que, siempre con fuerte acento retórico, ensalza la grandeza de la función episcopal, ahora profundamente degradada:

Ahora todos, tanto los extraños como los que son de los nuestros, sólo conocen un lugar de la vergüenza y de la maldad: la sede de los sabios antes respetada, el recinto de los mejores, este santuario embellecido por los coros angelicales, el cancel del altar que separa los dos mundos, el eterno y el perecedero, la frontera entre los dioses y los mortales. Así era antes, ahora es objeto de burla pues el acceso está abierto a todos: la puerta no está cerrada y me parece escuchar al heraldo que grita: «Venid aquí cuantos practicáis el mal, vergüenza de la humanidad, glotones, vanidosos, impúdicos, soberbios, borrachos, giróvagos, insolentes, afeminados, mentirosos y violentos, perjuros, vosotros que devoráis al pueblo, que con manos rapaces cogéis las riquezas ajenas, envidiosos, fraudulentos, falaces, aduladores de los poderosos, leones con los humildes, ambiguos servidores del momento que pasa, pulpos famosos porque cambian de color según las rocas; vosotros esposados hace poco, llenos de ardores (juveniles), con la pelusa aún en las mejillas [...]; venid confiados, pues la rica cátedra os está preparada. Inclinad vuestro joven cuello a la imposición de la diestra que está extendida con benevolencia para todos, incluso para aquellos que no lo desean» (Carmen II, 1, 13, vv.66-93).

\footnotetext{
${ }^{21}$ Lo justifica en su Carmen II, 1, 12 donde, después de calificar como carniceros a algunos de sus colegas, añade con ironía mal disimulada: «Presentaré mis argumentos sin dar nombres para que no parezca que yo quiero desvelar lo que debe permanecer oculto».

${ }^{22}$ Cfr. J. Torres-R. Teja, «A dispute of Episcopal Legitimacy: Gregory Nazianzen and Maximus in Constantinople», A. Fear-J. Fernandez Ubiña-M. Marcos (eds.), The Role of the Bishop in Late Antiquity. Conflict and Compromise, London, 2013, pp.13-30.
} 
Este pasaje refleja hasta qué punto se había ya difundido la idea de que, como dirá siglos después el gran humanista español Luis Vives, con Constantino había entrado el diablo en la Iglesia: «Entró el príncipe en la Iglesia, no como un verdadero y sincero cristiano, cosa que fuera venturosa y deseable, sino que introdujo consigo la nobleza, los honores, las armas, las insignias, los triunfos, la arrogancia y el sobrecejo, el fasto, la soberbia. Quiero con ello decir que el príncipe entró en la morada de Cristo acompañado del diablo» ${ }^{23}$. Al igual que sucederá con los hombres de la Reforma, Gregorio es también víctima del espejismo de una preconstantiniana Iglesia de los mártires, libre de influjos mundanos, y atribuye la situación presente a la acción del diablo quien, consciente de haber fracasado en su acoso a la Iglesia con las persecuciones, sabía que el método más eficaz era ahora corromper a sus dirigentes: «Como él sabía que el ejército era poderoso, ataca a los jefes, llevado de su odio destructor, pues sabe que, cuando el general cae, todo el ejército flaquea» (Carmen II, 1, 13, vv. 5153). Con un humor bastante sarcástico, el obispo capadocio concluye que en todo esto sólo se aprecia un aspecto positivo, la posibilidad de que «cuando uno os observe, tome el camino contrario. Esta es la única ventaja de vuestra maldad» (Carmen II, 1, 13, vv. 114-115). Un sarcasmo que recuerda a Paladio de Helenópolis cuando apuntaba, como ya he recordado, que Teófilo de Alejandría elegía a buenos obispos sólo cuando se equivocaba.

Además de las críticas de carácter general como las recogidas hasta aquí, Gregorio desciende al terreno de lo concreto cuando enumera como uno de los vicios más difundidos entre sus colegas sus veleidades en materia dogmática, bien en función de las preferencias del poder imperial, bien por sus rivalidades personales, su orgullo y hasta su tren de vida suntuoso, ostentoso y relajado:

Pablo es mi Dios, Pedro el tuyo, Apolo el del otro. Cristo ha sido atravesado en vano por los clavos de la cruz pues tomamos nuestro nombre, no de Cristo, sino de los mortales [...] Hasta tal punto nuestros ojos están cegados por el afán de vanagloria, o de riquezas, o por los celos perniciosos y corrosivos que ofuscan nuestra vida [...] El pretexto es siempre la Trinidad pero, en realidad, se trata de odios increíbles (Carmen II,1,13,vv.154-161) ${ }^{24}$.

Esta versatilidad en materia dogmática, que tan bien atestiguada está por otras muchas fuentes de la época, provoca la indignación rabiosa del Nacianzeno expresada en su Autobiografía, casi en un grito dramático contra los obispos oportunistas:

Nosotros lanzamos a todo el mundo este grito: iQuienquiera que lo desee, que venga aquí, incluso si ha cambiado de fe dos o más veces! El escenario del espectáculo está abierto a todos; el mercado también está abierto. Que nadie se marche

\footnotetext{
${ }^{23}$ J. L. Vives «De la condición de los cristianos bajo el turco», Obras Completas, Madrid, 1968, p. 69 (trad. L. Riber).

${ }^{24}$ Vid. otras descripciones de estas guerras eclesiásticas en II, 1, 10, vv.13-18; II, 1, 14, vv.7-10; II, 1, 17 , vv. 91-99.
} 
sin haber hecho negocios [...] No es de inteligentes atenerse a una sola convicción religiosa; es conveniente experimentar muchas salidas en la vida (Carmen II, 1, 11, vv. 1725-1733).

La historia de las disputas dogmáticas desde Constantino, en especial las provocadas por el arrianismo, había hecho patente la facilidad con que los emperadores podían lograr que la mayoría de los obispos se plegasen a su voluntad en cuestiones doctrinales. Los numerosos concilios celebrados durante el reinado de Constancio II habían sido un banco de pruebas, y el propio Gregorio había vivido en sus carnes la sumisión de sus colegas a la voluntad de Teodosio en el concilio celebrado en el 381 en la capital del Imperio. Por esto con amargura e indignación recuerda una y otra vez que «sólo profesan aquellas creencias que agradan al poder imperial» (Carmen II,1,11, v.1709) y explota su cólera contra esos traficantes de la fe, como los denomina en otra ocasión, en versos satíricos en que el servilismo episcopal adquiere tonos de parodia cínica: «Son como leones respecto a los inferiores, pero como perros ante los superiores; tienen el olfato fino para toda suerte de manjares; siguen la huella de los poderosos, no la de los sabios; honran al que les complace, no al que es útil» (Carmen II,1,12, vv. 339-342) .

En otro lugar evoca el entourage que rodea al emperador, en el que los eunucos constituían un elemento significativo, y contrasta el comportamiento adoptado por él mismo con el indigno servilismo de otros obispos:

Todos manifiestan temor al orgullo de los altos magistrados, especialmente de los consejeros más íntimos, totalmente desprovistos de virilidad, salvo en lo que afecta al dinero - qué pensar de personas como éstas y de su forma de comportarse agolpándose en las antecámaras del palacio, presentando acusaciones, dejándose sobornar de forma vergonzosa o aprovechándose de la buena fe de forma indecente [...]- Sólo yo me he hecho desear más bien que odiar [...] dejando a otros las puertas de los detentadores del poder (Carmen II,1,11, vv. 1424-1435).

Pero es, sobre todo, la vida desenfrenada de muchos jerarcas eclesiásticos lo que provoca la mayor indignación de Gregorio inspirando sus sátiras verdaderamente menipeas, y lo que ocupa más espacio en sus poemas. Así en el titulado De se ipso et de episcopis dedica casi treinta versos difícilmente traducibles a enumerar las pasiones que los dominan en cuanto hombres casados y propietarios de tierras: la gula exacerbada, las fiestas obscenas, la lujuria incontrolada, el concubinato, la vida relajada en general, entre lujos, pasiones y refinamientos de todo tipo (Carmen II,1,12, vv. 611633). Vuelve sobre el tema en su Autobiografía en uno de los pasajes más conocidos y de más alto nivel literario. Pone de relieve aquí que su modus vivendi de tipo monástico como obispo de Constantinopla provocaba las iras de sus colegas, ya que dejaba al descubierto, por contraste, sus muchos vicios. El pasaje puede ser considerado una especie de estereotipo del buen y del mal obispo:

Nosotros hacemos halagos, tú no halagas; nosotros reverenciamos los tronos de los poderosos, tú, en cambio, veneras la piedad; nosotros gustamos de comidas sucu- 
lentas, tú de la frugalidad; nosotros somos esclavos de las circunstancias y de los deseos de la gente orientando siempre nuestra barca al viento que sopla y camuflando nuestros propósitos de mil colores a la manera de los camaleones; sin embargo, en ti encontramos la misma ausencia de ductilidad que en un yunque (Carmen II, 1, 11, vv. 704-712).

Fustiga el obispo capadocio en estos versos a los obispos que lo habían forzado a abandonar la sede episcopal de Constantinopla en el 381 atribuyendo su acción, no sin una cierta dosis de superioridad y autocomplacencia, a la 'envidia' (phthonos) que sentían hacia él. Una envidia provocada por el complejo de inferioridad moral e intelectual que percibían aquellos que con ironía denomina «magníficos y excelentes ( $k a l o i$ kai agathoi) colegas pastores (sympoimenes)» en unos versos que parecen inspirados en Aristófanes:

Reventaban de envidia [...] (pues la rusticidad no soporta la cultura), abusaban de mi enfermedad -consecuencia de mis trabajos-y del hecho de que yo no estaba apegado a un trono tan elevado [...] y me dejaron partir de allí de buen grado, ellos, los muy amigos, como si se tratase de soltar el lastre pesado de un navío, pues resultaba que yo era para estos malvados una carga insoportable. Pero después elevan a Dios sus plegarias como si fuesen puros y santos y le ofrecen piadosas ofrendas expiatorias. Santificarán al pueblo con palabras sagradas aquellos mismos que me expulsaron de allí de forma malvada, aunque no muy contra mi voluntad. Y es que constituía una gran vergüenza ser contado entre estos traficantes de la fe. Algunos son descendientes de recaudadores de impuestos que no tenían en su mente otro propósito que falsificar las cuentas. Otros provienen de la usura y de la mesa del cambista; otros del arado, tostados por el sol, otros de la azada, o del hacha que nunca descansa; otros han dejado el remo o el ejército pues expelen aún olor a sentina o tienen el cuerpo cubierto de cicatrices, pero son tan insolentes que se creen superiores a los gobernantes o a los jefes militares; otros provienen de la fragua y todavía sus carnes no han podido limpiarse del hollín; otros son estafadores dignos del látigo, merecedores de la rueda de molino. Antes de pagar el precio del rescate a sus dueños, si es que pueden encontrar un pequeño alivio a sus fatigas, se transforman en insolentes y engañan a cualquiera del pueblo, bien con la persuasión, bien con la violencia. Corren hacia lo alto, como escarabajos hacia el cielo, haciendo girar la pelota del mundo, vista, como antes no ya la del estiércol ${ }^{25}$, sin volverla hacia la tierra: creen, por ello, poseer el poder de los propios seres celestiales y se expresan de forma siniestra, aunque no sepan contar los dedos de sus pies o de sus manos (Carmen II, 1,12, 136-175).

${ }^{25}$ C. Crimi, op. cit., en su traducción hace notar que la expresión, con un claro valor proverbial, evoca la fábula de Esopo El águila y el escarabajo a la que alude un famoso pasaje de Aristófanes, La Paz 129ss. Por mi parte, pienso que este pasaje ha podido inspirar el de Paladio de Helenópolis cuando califica a Teófilo de Alejandría de escarabajo pelotero: vid. infra, Dial. VIII, 37-39. 
La amargura expresada en forma tan irónica domina e invade los juicios de Gregorio de Nacianzo sobre obispos que, no hay que olvidarlo, eran sus semejantes y colegas. Las críticas son tan acerbas y excesivas que, aunque tengan un fundamento en el bajo nivel moral e intelectual de la mayoría, pierden parte de su credibilidad. Podría recordarse que Sinesio de Cirene, al cambiar su cátedra de filósofo por la de obispo, se sorprendió de la mala fe con que frecuentemente se acusaban unos clérigos a otros: «los presbíteros acusan a otros presbíteros de actos ilegales, no quiero afirmar que falsamente, pero sí que con maliciosa determinación $\rangle^{26}$. Es cierto que, después de su experiencia en Constantinopla, solo podía esperar lo peor y en parte no se equivocó: el hombre que fue elegido para sucederle era, como ya he recordado, la antítesis de su ideal episcopal; no sólo no era ni un monje ni un intelectual, sino un senador de Constantinopla, originario de Tarso, que ni siquiera estaba bautizado y era totalmente ignorante en materia de teología ${ }^{27}$. J. Bernardi, quizá el mejor conocedor de la obra literaria de Gregorio, ha explicado el origen de críticas tan cáusticas y destructivas en la amarga experiencia del concilio del 381, pero hace notar que, aunque había en la época muchos malos obispos, le plus souvent, Grégoire ne s'embarrasse guère de distinctions et confond allégrement ses confrères dans une même réprobation ${ }^{28}$. Sería una equivocación -afirma el estudioso francés- ver en estas críticas sólo el resentimiento de un noble de vieja alcurnia ante la promoción masiva de advenedizos. Aunque en Constantinopla y durante el concilio debió de tomar conciencia de hasta qué punto el episcopado se había transformado en poco tiempo en una vía rápida e inesperada de promoción social, Gregorio no perdona tampoco ni a los nobles ni a los intelectuales. El mismo J. Bernardi señala también que ciertas caricaturas de 1os obispos satirizados se parecen tanto a Máximo que es posible que el Nacianzeno estuviese pensando especialmente en los obispos egipcios ${ }^{29}$. Puede ser así, y recordaremos a continuación la imagen que Paladio de Helenópolis ofrece de la cabeza de éstos, Teófilo de Alejandría. Pero veremos también que el nivel moral de los obispos de Asia Menor o de Siria apenas se diferenciaba del de los egipcios o de los satirizados por Gregorio, sin ofrecer nombres. En cualquier caso, lo cierto es que la virulencia de sus sátiras no conoció límites cuando se trataba de los hermanos en el episcopado, circunstancia que sólo puede explicarse en el contexto de la parrhesia que caracterizó a los filósofos de la Antigüedad y del tono y trasfondo retóricos que envuelven sus poemas. Además de obispo y teólogo, Gregorio Nacianzeno fue un filósofo, un rétor y un poeta y también un sofista, según una reciente observación de Alberto J. Quiroga: Gregory of Nazianzus took recurse to the stereotipal figure of the sophist in censuring religious enemies, both within and outside the church ${ }^{30}$. Podría recordarse, a este respecto, la

${ }^{26}$ Sin. Cyr., Ep. 66,1

27 Vide N. McLynn, op. cit., 1997, p.303

28 J. Bernardi, op. cit., 1995, p. 325

${ }^{29}$ Ibid. p.326

${ }^{30}$ A. J. Quiroga Puertas, «Preaching and Mesmerizing. The Resolution of Religious Conflicts in Late Antiquity», A. Fear et alii, op. cit., p. 193; sobre la concepción de la retórica de Gregorio, sin olvidar que él mismo era un rétor profesional, vid. N. McLynn, «Among the Hellenist: Gregory the Sophist», J. Bortnes-T. 
epístola 11, dirigida a Gregorio de Nisa reprochándole que hubiera abandonado su actividad como lector en la Iglesia por «preferir el nombre de rétor al de cristiano». Pero se lo recrimina en una carta que es una obra de arte de la retórica, prueba de su exquisita formación literaria. J. Bernardi ha definido a Gregorio como intelectuel du tempérement et rhéteur de formation ${ }^{31} \mathrm{y}$, como sutil conocedor que es de su amplia producción, al comentar su Invectiva Contra Juliano (Oratio IV), observa que, aunque ésta fue una obra de juventud cuya fiereza en las críticas puede sorprender e, incluso, escandalizar, con todo, le dent de Grégoire ne perdrá rien de sa dureté avec les années: les évêques, à leur tour, lui serviront de cible. Le vieil évêque dimissionaire du second siège de la chrétienté ne leur ménagera pas de dures verités ${ }^{32}$. Me he limitado a recoger las críticas contra los obispos rastreando su obra poética, quizá la más expresiva, pero en su Oratio 42 de despedida de la sede episcopal en el 380 se expresa con una similar dureza y amargura sobre aquellos que, escondiéndose bajo el nombre de teólogos, se atreven a dirigir las almas sin la más mínima preparación y acomodan sus dogmas a los de los emperadores de turno.

\section{PALADIO DE HELENÓPOLIS Y SUS CRÍTICAS A LOS OBISPOS DE ASIA, EGIPTO Y SIRIA}

Lo que sucedió en el 397, a la muerte de Nectario, el sucesor de Gregorio en Constantinopla, lo describió otro obispo de la época, Paladio de Helenópolis, en términos que no desmerecen, por su dureza, el lenguaje empleado por el obispo capadocio:

Fue ésta la ocasión para que se presentasen como candidatos algunos indeseables, pero ansiosos de ocupar una cátedra tan honorífica: hombres que no eran hombres, presbíteros por su ordenación, pero totalmente indignos del sacerdocio. Algunos de ellos llamaban a las puertas del pretorio; otros ofrecían dones como soborno; otros, incluso, se ponían de rodillas como suplicantes ante la plebe ${ }^{33}$.

Era, sin duda, a obispos como éstos a los que se refería Agustín cuando apuntaba muy expresivamente: «Tienen el título, ocupan la cátedra, pero son como espantapájaros en el viñedo» ${ }^{34}$.

Hombre de vasta cultura teológica en cuanto seguidor de Orígenes, después de haber sido monje en un monasterio de Egipto, Paladio fue consagrado por Juan Cri-

\footnotetext{
Häag (eds.), Gregory of Nazianzus: Images and Reflections, Copenhagen, 2006, pp. 213-238, especialmente el apartado «Gregory the literary professional», pp. 220-224.

31 J. Bernardi, Gregorius Nazianzenus. Oratio IV, ed. y tr. fr., Paris, 1983, Introduction, p. 20.

${ }^{32}$ Ibid., p. 57.

${ }^{33}$ Pal. Hell., Diálogo, V, 46-50 (Palladios, Dialogue sur la vie de Jean Chrysostome I, Introd., texte critique, trad. et notes de A.M. Malingrey, Paris, 1988, S.Ch. 341); la atmósfera de intrigas y ambiciones que se desataban cuando quedaba vacante una cátedra episcopal fueron bien descritas por Juan Crisóstomo en su tratado De sacerdotio III, 3.

34 August., Sermo Guelf 32,6 (P.L.S. II,642)
} 
sóstomo obispo de la pequeña ciudad de Helenópolis en el norte de Asia Menor poco después del 398. En su conocido Diálogo sobre la Vida de Juan Crisóstomo, escrito en defensa de éste, Paladio se muestra feroz en sus diatribas contra los obispos que se enfrentaron a Juan cuando trató de limpiar las sedes episcopales dependientes de su jurisdicción de aquellos personajes indeseables que, además, habían sido los responsables, en última instancia, de su destitución como obispo de Constantinopla en el famoso Sínodo de la Encina del 404 y del subsiguiente destierro. El descontento surgido a raíz de estos enfrentamientos fue aprovechado por el ambicioso Teófilo de Alejandría, quien se trasladó personalmente a Constantinopla para encabezar la maniobra: se trató de una verdadera conjura descrita por Paladio con unos términos en los que Teófilo parece rivalizar con el protagonista del salustiano Adversus Catilinam. En otra ocasión he definido la obra como «apologia, pamflet, parénesi: impossibile da incasellare in un genere preciso, forse perchè in essa più generi si intrecciano e concorrono alla sua composizione ${ }^{35}$. Pero, en el fondo, se trata de un diálogo histórico, y como tal aparece calificado en el único manuscrito que lo ha conservado integralmente, aunque cargado de retórica y con un tono que recuerda también muy de cerca el lenguaje de la diatriba cínica. Comienzo recordando algunos de los juicios que Paladio aplica a Teófilo: «Perro que muerde de improviso [...] sus ojos están inyectados de sangre al modo de un dragón [...] Observa torvamente como hacen los toros» (Dial.VI, 125-127); «impulsivo por naturaleza, temerario, fogoso y pendenciero»; «no había nada que viese y sobre lo que, con ansias irrefrenables, no pusiese las manos»; «no había en él ni prudencia, ni buen juicio, ni reflexión atenta. Llevado de estos impulsos irracionales [...] declaraba la guerra despiadada contra cualquiera que se atrevía a hacerle frente» (Dial. IX, 22-23); «como escarabajo que se revuelve en la inmundicia, esparcía el suave olor para tapar su maloliente inmundicia» (Dial. VIII, 37-39); «experto en maquinaciones diabólicas que ponía en práctica distribuyendo grandes cantidades de dinero» para «conquistar con halagos y promesas de mayores proporciones las simpatías de los clérigos semejantes a él en las imposturas» (Dial. VIII, 57-58). En otro lugar, sin mencionar a Teófilo, ataca la simonía de aquellos obispos sacrílegos que habían depuesto a Juan y «han depredado la iglesia de los apóstoles privándola de un tan gran maestro; aquellos que han vendido por dinero las ordenaciones sagradas» (Dial. XX, 638-641). En la misma línea que Paladio, Martirio de Antioquía, otro panegirista de Juan Crisóstomo, califica a Teófilo como «hombre poco inferior al diablo por naturaleza, pero muy superior a él en astucia» ${ }^{36}$.

\footnotetext{
${ }^{35}$ S. Acerbi, «Palladio contro Teofilo», op. cit., vol. II, 1997, p. 372; sobre el papel de Teófilo en el juicio y deposición del Crisóstomo, vid. et. S. Acerbi, «Accusatore, testimone e giudice: il ruolo dei vescovi di Alessandria nella sinodo della Quercia e in altri concili posteriori», Giovanni Crisostomo, Oriente e Occidente tra IV e V secolo. XXXIII Incontro di studiosi dell'Antichità cristiana. (Roma, 6-8 mayo 2004), Studia Ephemeridis Augustinianum 93, Roma, 2004, pp. 713-720.

${ }^{36}$ Martirio de Antioquía, Oratio funebris in laudem sancti Iohannis Chrysostomi 38, 1 (M. Wallraff-C. Ricci, Oratio Funebris In Laudem Sancti Iohannis Chrysostomi: Epitaffio Attribuito a Martirio di Antiochia (bhg 871, Cpg 6517), ed. y tr. it., Spoleto: Fondazione Centro italiano di studi sull'Alto Medioevo, 2007).
} 
La narración de la forma en la que el alejandrino reclutó en Egipto y Asia Menor, durante su viaje a Constantinopla, a obispos dóciles dispuestos a votar la deposición de Juan constituye una página muy explícita de la degradación moral del episcopado de la época y de la total sumisión de los obispos de la khora egipcia al de Alejandría, algo bien conocido por otras muchas fuentes contemporáneas. El texto es también un elocuente documento del desprecio y sentido de superioridad racial que los de origen griego, como es el caso de Martirio de Antioquía, sentían hacia los egipcios:

Reunió a los obispos de las iglesias egipcias a los que ya desde mucho antes, desterrándolos y cambiándolos, los tenía sometidos hasta tal punto que actuaban a una sola señal suya, más encadenados por la fuerza que los esclavos. Sus nombres semibárbaros están formados con las viejas abominaciones de Egipto, su voz y su lengua son totalmente bárbaras, y su modo de obrar imita su voz. Habiéndolos obligado a embarcarse en las naves, los expidió por el camino más breve diciéndoles sólo esto: «Partamos para llevar a cabo una acción necesaria» [...] Él, por su parte, siguiéndolos, se dirigió por tierra sembrando engaños para los obispos de las ciudades a lo largo de su recorrido, y eran muchas, sirviéndose de hombres pestíferos, capaces de todo por una ganancia injusta [...] Una vez que llegó al estrecho de mar que separa Bitinia de Tracia y que se atraviesa rápidamente en pocos estadios, se detuvo allí esperando las naves que venían de Egipto. Cuando llegaron con una carga de injusticia y una mercancía de ilegalidades, con el padre de la envidia como timonel, los dejó en la región de Bitinia organizando reuniones de estúpidos, los unos con los otros, mientras él, una vez llegado a Constantinopla -el cómo no lo diré pues me avergüenzo de contar embustes marineros protagonizados en tierra-, dejando de lado la iglesia, como si desde hacía tiempo le resultase algo extraño, se dedicó a frecuentar las casas de los ricos (Ibid. 38-39).

No me voy a detener en narrar las circunstancias bien conocidas que culminaron en el juicio y deposición de Juan Crisóstomo. Me limitaré a recordar que se había creado numerosas enemistades y odios acérrimos cuando procedió a deponer a varios obispos simoniacos de Asia Menor. La práctica de compra de los nombramientos eclesiásticos, que en Occidente recibirá a partir de Gregorio Magno el nombre de 'simonía ${ }^{37}$, estaba tan generalizada que Paladio pone en boca de seis obispos denunciados por Juan, que habían comprado su ordenación al obispo de Éfeso Antonino, esta sorprendente justificación:

\footnotetext{
${ }^{37}$ Greg. Magno., Ep. XI, 28, donde se sirve de la expresión simoniaca haeresis; parece que el primer texto cristiano en que aparece el término asociado a Simón Mago es en la epístola de Dámaso Ad Gallos episcopos 10: non Simonis pecunia vel gratia. A Simón Mago alude también Gregorio de Nacianzo en una de sus invectivas para criticar los cambios repentinos de profesión de algunos para acceder al episcopado: ;Ayer Simón Mago, hoy Simón Pedro! (Carmen II, 1, 12, vv. 425- 430). Basilio de Cesarea fue uno de los primeros obispos en denunciar la venta de ordenaciones por parte de algunos coreobispos de Capadocia, que introducen la kapeleia, la venta de ordenaciones, encubierta bajo el nombre de piedad: Ep. 53.
} 
Nosotros hemos pagado, es cierto, y hemos sido ordenados pero pensábamos que esto era un medio legal para librarse de las cargas municipales (tou bouleuteriou). Ahora solicitamos permanecer al servicio de la Iglesia, si esto es conforme a la ley divina; de lo contrario, exigimos recuperar el dinero que hemos pagado pues algunos de nosotros han tenido que empeñar hasta el ajuar de nuestras esposas (Dial. $\mathrm{XV}, 21-26)^{38}$.

No sorprende que una de las siete acusaciones presentadas contra este Antonino, un personaje profundamente corrupto, fuera la de que «su norma consistía en vender las ordenaciones de obispos en función de la riqueza de los candidatos» (Dial. XIII, 172-174). Juan Crisóstomo logró deponerlo en el año 400 junto con otros seis obispos sufragáneos de la provincia de Asia que le habían comprado la ordenación. Pero, cuando Juan Crisóstomo fue depuesto, se vieron restituidos en sus sedes, y el obispo elegido para sustituir al fallecido Antonino fue enviado a prisión y reemplazado por un eunuco degenerado. Paladio denuncia estos hechos con un lenguaje muy similar al utilizado por Gregorio de Nacianzo en sus diatribas contra los malos obispos. Comienza comparando los criterios seguidos por unos y otros en la selección de los candidatos a ocupar las cátedras episcopales:

Las ordenaciones de Pedro y Juan se hacían entre el ayuno y la plegaria, tras un examen (dokimasia) de los candidatos y en el temor de Dios. Las de ellos (los enemigos de Juan), por el contrario, entre borracheras, desenfrenos e intercambios de vergonzosos regalos en provecho de los desechos de la humanidad, menos dignos, incluso, que las criaturas desprovistas de razón, los puercos y los perros [...] A estos compañeros de los mimos y de los judíos se les confían por parte de nuestros sabios los secretos del sacerdocio, como si fueran amigos del Salvador. Por culpa de ellos, los verdaderos fieles huyen de los lugares de oración (Dial. XV, 60-69).

Pasa después Paladio a trazar una imagen caricaturesca de este eunuco, cliente, a su vez, de un tribuno de nombre Víctor, que fue entronizado en la cátedra episcopal de Éfeso, santificada y prestigiada por San Juan Evangelista, mientras que Heraclio, al que el Crisóstomo había consagrado para sustituir a Antonino, había sido encarcelado:

Seguramente ha llegado a vosotros la noticia del golpe de mano que se ha llevado a cabo sin ningún motivo válido en la iglesia de Éfeso en el lugar, o más bien, el trono de Juan el Evangelista [...] Después de ordenar al tribuno del eunuco Víctor, le entronizaron e hicieron consumirse en la prisión en que aún continúa aquel a quien habían entronizado sesenta obispos [...] Y pluguiera al cielo que, al menos, este eunuco que había sido ordenado hubiera tenido una vida respetable. Hubiera sido sólo un mal menor. Pero no. Era un gusano de tierra, esclavo de su vientre, desen-

\footnotetext{
${ }^{38}$ Sobre el tema vid. L. De Salvo, «Simonia e malversazioni nell'organizzazione ecclesiastica del IV-V secolo», R. Soraci (ed.), Corruzione, repressione e rivolta morale nella Tarda Antichità. Atti del Convengo Internazionale Catania 11-13 dicembre 1995, Catania 1999, esp. pp. 374-377; S. Acerbi, op. cit., 1997, pp. 371-381.
} 
frenado, desvergonzado, borracho, prostituido, vendido, vil, lujurioso, apto para haber sido marcado por el hierro desde su nacimiento, criatura asexuada, loco furioso. Había llevado a sus espaldas, según he oído decir con frecuencia, a actrices de teatro durante las bacanales de sátiros en las que, coronado totalmente de hiedra, sostenía con la mano una crátera y libaba el vino para imitar al Dionisos de la mitología. Y todo esto lo ha hecho, no antes de haber sido iniciado en Cristo, sino después de su bautismo, poniendo así de manifiesto que no creía en la resurrección [...] En cuanto a su continencia, no tiene ningún mérito pues se debe al hierro y es estéril por causa de su propia infamia (Dial. XV, 69-100) ${ }^{39}$.

En un estudio reciente Rita Lizzi ha recordado estos pasajes de Paladio resaltando lo difundida que estaba la simonía en la diócesis de Asia, donde, escribe, il mercato di vescovati sembra avvenisse su scala assolutamente insolita, trovando acquirenti soprattutto fra $i$ curiali che volevano evadere i propi obblighi e accettavano di comprare le ordinazioni in proporzione alle entrate che garantivano ${ }^{40}$. Pero el vicio estaba muy generalizado en casi todas las iglesias de Oriente. Sin abandonar a Paladio y su Diálogo, vale la pena recordar su semblanza del obispo Porfirio, que sucedió en Antioquía al gran Flaviano, el mismo que había consagrado presbítero a Juan Crisóstomo. Porfirio fue uno de los que más se distinguieron en la persecución de los partidarios de Juan. Comienza Paladio su 'retrato' con la descripción de su pasado como presbítero en Antioquía aprovechándose del cargo y de sus influencias para vender prebendas y ordenaciones a costa de la buena fe de los obispos:

Enfrentado constantemente con los piadosos obispos de las ciudades próximas aduciendo que pertenecía a la ciudad más importante y que tenía incluso a magistrados bajo su dependencia, traficaba a costa de su cargo. Sirviéndose de las intrigas en las santas ordenaciones, él se servía de su habilidad en su forma de actuar entre los obispos, induciéndolos a ordenaciones contra su voluntad, arrastrados, podría decirse, por el viento. Y es que la adulación es temible cuando va unida a la maldad, como expresó bien Menandro, el poeta cómico [...] (Pal. Hell., Dial. XVI, 30-41).

Pasa después a relatar su vida privada de sodomita en tonos satíricos muy similares a los utilizados para retratar al eunuco que había sido consagrado en Éfeso, y con expresiones que manifiestan una parrhesía inspirada, aparentemente, en el vocabulario de la comedia nueva ateniense:

\footnotetext{
${ }^{39}$ La ordenación de eunucos había sido prohibida en el concilio de Nicea, pero son numerosos los casos conocidos en que esta prohibición era ignorada. No sé hasta qué punto se trató de una práctica especialmente frecuente en la iglesia de Éfeso pues años después Nestorio denunciará el caso de Eterico, del que dice que era un campesino inculto que después sirvió como eunuco en la corte imperial y «como tenía gran ambición de grandeza y poder, fue hecho obispo» de Éfeso, Libro de Heraclidas, pp. 31-32. Desconozco el motivo por el que no aparece en la Prosopografia cristiana de la Diócesis de Asia de S. Destephen, Prosopographie Chrétienne du Bas-Empire. 3 Diocèse d'Asie (325-641), Paris, 2008.

${ }^{40}$ R. Lizzi «La vendita di cariche ecclesiastiche: interdizioni canoniche e provvedimenti legislativi dal IV al VI secolo», Cristianesimo nella Storia, 33,2 (2012), p. 467.
} 
No sólo era ajeno a la moderación en los placeres de la carne, sino que ello le resultaba tan insoportable como el perfume a un buitre, hasta el punto de que se ganó la fama de practicar el vicio de la sodomía. Y es que la naturaleza ha establecido límites y barreras a nuestros placeres, como todo el mundo sabe. Pero él, franqueando esta barrera, removiendo sus límites, violando la ley, dio origen a estas sospechas a base de arruinarse y comer con hechiceros y aurigas y todos aquellos representados en los antiguos mitos mediante pantomimos impropios que contorsionan sus brazos y sus piernas. No se avergonzó de hacerse cargo de la defensa de estos hechiceros y de mantener buenas relaciones con ellos según consta en las acusaciones recogidas en actas de numerosos magistrados ${ }^{41}$, pues no parece haber conocido el proverbio de que «lo que no se puede hacer, no provoques la sospecha de que lo haces». Se cuenta que, además de estos escándalos, hizo fundir, después de su ordenación, vasos sagrados y ofreció las ganancias a los magistrados. Con ello parecía dominar, no con la palabra, sino mediante la tiranía, a aquellos que tenían la desgracia de caer bajo su dependencia (Dial. XVI, 31-63).

Termina Paladio esta durísima semblanza narrando la ordenación episcopal de Porfirio mediante una estratagema que recuerda muy de cerca la que se había utilizado en Constantinopla para consagrar de noche y en secreto a Máximo el cínico frente a Gregorio de Nacianzo. Después de lograr que Constancio, un hombre íntegro que estaba a punto de ser ordenado, fuese exiliado al Oasis de Egipto - lo que evitó huyendo a Chipre-, y una vez que se desembarazó también de los presbíteros que lo apoyaban, Porfirio aprovechó que la mayor parte del pueblo de Antioquía había acudido a presenciar las competiciones olímpicas que se celebraban en las afueras de la ciudad, junto al famoso santuario de Dafne, para ser ordenado en secreto: «Habiendo penetrado en la iglesia con los obispos ya mencionados y un pequeño número de presbíteros, fue ordenado en secreto, con la puertas cerradas y con tal rapidez que ni siquiera les dio tiempo de recitar las plegarias hasta el final por miedo a ser sorprendidos» (Dial. XVI, 104-108) ${ }^{42}$.

\section{LA RETÓRICA AL SERVICIO DE LOS ODIOS ECLESIÁSTICOS}

He intentado demostrar la importancia desempeñada por la retórica en la crítica a colegas en el episcopado por parte de algunos escritores cristianos de la Segunda Sofística, en especial Gregorio de Nacianzo y Paladio de Helenópolis. Pero al margen de exageraciones y juegos oratorios, al leer a éstos y otros autores de la época sorprende hasta qué punto los enfrentamientos doctrinales y las luchas por el poder desataron en

\footnotetext{
41 Alusión, sin duda, al hecho de que las prácticas mágicas estaban penadas con dureza por la legislación imperial de la época: vid ahora G. Marasco, «L'accusa di magia e i cristiani nella tarda antichità», Augustinianum 51, 2 (2011), pp. 367-421.

42 Para la ordenación de Máximo, vid. la narración de Gregorio en Autobiografía, vv. 887-1000 y sobre todo el affaire, vid. ahora J. Torres-R. Teja, op. cit, pp.14-29.
} 
la Iglesia entre correligionarios cristianos unos odios más irreconciliables de los que habían caracterizado los enfrentamientos entre las escuelas filosóficas griegas. El triste destino del que fue víctima Juan Crisóstomo puede servir de colofón a este ensayo. Juan no sólo fue uno de los hombres de conducta más intachable que conoció el cristianismo en la Antigüedad, sino que también desplegó enormes esfuerzos como dirigente eclesiástico y como teórico del sacerdocio por elevar el nivel moral de los clérigos y obispos de su tiempo. Pero estos mismos esfuerzos le acarrearon oscuros odios que culminaron con su destitución como obispo de Constantinopla, su exilio y su muerte. El principal responsable fue otro de los obispos con más poder y menos escrúpulos morales de su tiempo, Teófilo de Alejandría. Con la colaboración de otros eclesiásticos que poco se le parecían, como es el caso de San Jerónimo, el papas alejandrino no se contentó con acabar con la vida del Crisóstomo, sino que también se sirvió de su pluma y de su habilidad retórica para ensuciar su memoria con el objetivo de que pasase a la posteridad como modelo de corrupción y de herejía y viva encarnación del Anticristo.

En el 406, cuando Juan se encontraba ya en su exilio en Armenia, enfermo y próximo a morir, Teófilo escribió una carta pastoral que constituye una de las diatribas más inhumanas, vergonzosas y brutales entre obispos de las que tengo conocimiento. Teófilo redactó la epístola en su lengua nativa, el griego, pero contó con la inestimable ayuda de Jerónimo quien la tradujo al latín para que se difundiese también en Occidente. El texto original griego se ha perdido y en la colección epistolar de Jerónimo figura solamente el incipit, pues su contenido era tan escandaloso que fue suprimido en la tradición manuscrita. Pero se da la circunstancia de que algunos párrafos de la traducción latina fueron transcritos por autores como Facundo de Hermiana, quien calificó el texto como innormis et orribilis liber. Son las citas de esta carta pastoral de Teófilo, traducida en su momento por Jerónimo, las que reproducimos a continuación tal como fueron recogidas por Facundo de Hermiana:

Juan -dice Teófilo- persigue a los hermanos con el espíritu inmundo que ahogaba a Saúl; y de nuevo: Él ha dado muerte a los ministros de los santos. Le denomina corrompido e impío en la Iglesia de los primeros cristianos (Antioquía), pestilente, malvado (vesanum), con una mente enloquecida por un espíritu tiránico (tyrannicae mentis insanio furibundum), orgulloso en su locura por haber entregado su alma al diablo para que éste la pervirtiese. Todo esto lo recogemos tal como consta en el libro del bienaventurado Teófilo. Le denomina también enemigo de la humanidad, más audaz en sus crímenes que los bandidos, príncipe de los sacrílegos, oficiante de un sacerdocio impío, oferente de oblaciones sacrílegas, procaz y de cabeza durísima. Añade también que Juan no estaba atado por lazos que pueden ser rotos alguna vez, sino que, en mérito a sus delitos, escuchaba a Dios amenazando y diciendo: «Juzgad entre mi y Juan; yo esperaba que hiciese un juicio, pero hizo iniquidad y no justicia sino clamor». Dice también que, al igual que Satanás se ha transfigurado en ángel de luz, Juan no es aquello que aparenta ser; y le denomina, no sólo semejante a Satanás, sino también demonio inmundo, que arrastra como un torrente la porquería de las palabras; lo presenta, incluso, levantán- 
dose impíamente contra Cristo y como compañero del traidor Judas. Añade, también, que se ha demostrado que había levantado sus manos impías contra Dios; y lo que el apóstol Santiago dijo a propósito de las personas que desean las cosas de este mundo: «Vosotros pediréis y no recibiréis porque pedís mal», Teófilo asegura que Juan lo había dicho también a propósito de Cristo: «Se atrevió a decir en la iglesia que Cristo había orado y no había sido escuchado porque no había orado bien».

\section{Reproducimos también esta otra cita: de Facundo de Hermiana:}

¿Qué hereje ha blasfemado más gravemente que como ha blasfemado el bienaventurado Juan, según refiere el bienaventurado Teófilo? Afirma él, en efecto, que Juan se ha entregado a si mismo a la asociación de la impiedad de los judíos y ofrecido con su temeridad habitual lo que ofrecieron los judíos [...] Y añade todavía esto: Los arrianos y los eunomianos se alegran de las blasfemias de Juan contra Cristo; los judíos y los gentiles idólatras tienen justificación comparados con él. Y añade aún: No sólo no es cristiano Juan, sino que es peor que el rey de Babilonia, más malvado que los idólatras y los paganos es Juan. Tú, dice, recibirás en el presente la ignominia y en los siglos futuros, la pena eterna.

Al bienaventurado Teófilo le parece bien decir también esto: El Señor clamó y dijo: «Tomad a Juan y enviadle a las tinieblas exteriores»; y también: Ha fomentado durante largísimo tiempo su propio fuego ante el tribunal de Dios. Todo esto no habría logrado saciar la cólera y el furor de Teófilo, si no hubiera dicho también de este muy santo Juan que era necesario buscar para él otro castigo porque la gravedad de su crimen superaba el número de los tormentos.

Si alguien quiere comprobar que hemos reproducido no sólo sus pensamientos sino también sus mismas palabras, que lea el ingente libro, horrible no sólo por estas injurias, sino también por la repetida acumulación de maldiciones, que fue traducido por el presbítero Jerónimo. Con ello el propio bienaventurado Teófilo esperaba que por sus palabras los latinos supiesen qué tipo de persona había sido $\mathrm{Juan}^{43}$.

${ }^{43}$ Facundo de Hermiana, En defensa de los tres capítulos VI, V, 15-23 (Facundus d'Hermiane, Défense des Trois Chapitres (À Justinien), J. M. Clement et R. Vander Plaeste, texte critique; A. Fraïsse-Betoulieres, introd., trad. et notes, Paris, 2006, S.Ch. 471 y 479). La carta de Teófilo debe fecharse en el 406. La traducción a que alude es la Ep. 114 de Jerónimo, de la cual sólo se ha conservado el inicio, pues, como he señalado, sin duda fue censurada por la dureza de las acusaciones allí vertidas. Pero Facundo de Hermiana y también Pelagio, -quien en Def. VI (ed. Devreesse ( pp. 70-71) cita las invectivas más literalmente que Facundo-, conocían el texto de la traducción de Jerónimo. Sobre el total acuerdo de Jerónimo con las acusaciones de Teófilo y el vasallaje que demostró hacia éste, vale la pena citar lo que dice del Liber enormis en la carta a Teófilo en que le remite la traducción: «De tu obra admiro la utilidad que puede tener para todas las iglesias, de modo que quienes lo ignoran pueden aprender el respeto con que deben hacerse cargo de las cosas santas y servir al ministerio del altar de Cristo [...] Recibe, pues tu libro, o más bien el mío, o, para decirlo más exactamente, el nuestro; y, si quedas contento de mi, también lo estarás de ti. Al fin y al cabo para ti ha sudado mi ingenio $\mathrm{y}$ he intentado, con pobreza latina, acercarme a la elocuencia griega» (Ep.114, 2-3). 
Dos años antes, en el 404, Jerónimo había recibido otra carta de Teófilo para que también la tradujese al latín. La epístola, en la que el alejandrino justificaba los motivos por los que Juan había sido depuesto en el Sínodo de La Encina, parece que iba destinada al obispo de Roma. Jerónimo no tuvo escrúpulos en hacer de traductor, pero tampoco se ha conservado íntegra en su corpus epistolar, como fue el caso de la del 406 anteriormente mencionada, por el escándalo que podía provocar la dureza de las expresiones del alejandrino referidas al santo obispo de Constantinopla. Merece la pena reproducir el inicio de la carta, lo único conservado, para completar la imagen de Juan Crisóstomo que Teófilo y Jerónimo quisieron transmitir a la posteridad:

A pocos gusta al principio el veredicto de la verdad; pero el Seños dice por boca de profeta: «Mi juicio se abrirá paso como la luz» (Is. 51,4). Por eso, los que viven envueltos en el horror de las tinieblas, y no tienen la mente lúcida para comprender las circunstancias, terminan abrumados de vergüenza eterna y al final tienen que reconocer que sus esfuerzos han sido vanos. De ahí que también nosotros hayamos deseado siempre que Juan, que hasta hace poco regía la iglesia de Constantinopla, agradara a Dios y que nunca hayamos querido dar crédito a los motivos que le han llevado a su perdición, y en los que una y otra vez incurría por imprudencia. Pero él, y me callo otros desmanes suyos, recibió con familiaridad a los origenistas y a muchos los promovió al episcopado, y causando con ello no poco disgusto al hombre de Dios Epifanio, de santa memoria, que entre los obispos de todo el orbe brilló como un astro esplendoroso, mereció oír la sentencia: «Cayó, cayó Babilonia» (Is. 21,9$)^{44}$

Juan Crisóstomo trazó en su famoso tratado De Sacerdotio la imagen ideal del obispo cristiano. Paladio de Helenópolis, al escribir la defensa de Juan, presentó a su enemigo, Teófilo, como el poneros episkopos, el mal obispo por excelencia. Teófilo y Jerónimo unieron sus plumas para hacer de Juan la encarnación del mal en la Iglesia. Los objetivos de cada uno fueron totalmente opuestos, pero el instrumento siempre fue el mismo, la retórica al servicio de las luchas entre obispos. Concluyo este ensayo con las palabras con que un estudioso francés de Gregorio de Nacianzo sintetiza su trayectoria vital en una época corrompida y corruptora: Fuir, pour mener à l'écart une vie consacrée à l'ascèse contemplative, un siècle corrompue et corrupteur dont son calame traque les vices jusqu'au sein de l'Église, telle est bien l'aspiration qu'il exprime de façon récurrente dans son æuvre ${ }^{45}$.

${ }^{44}$ Hier., Ep. 113.

${ }^{45}$ F. Gautier, La retraite el le sacerdoce chez Grégoire de Nazianze, Turnhout, 2002, pp. 3-4. 